\title{
Administration of Neural Precursor Cells Ameliorates Renal Ischemia-Reperfusion Injury
}

\author{
Pamella Huey Mei Wang ${ }^{a}$ Telma T. Schwindt ${ }^{b}$ Gabriela Filoso Barnabé ${ }^{b}$ \\ Fabiana L.T. Mottab Patricia Semedo ${ }^{a}$ Felipe Caetano Beraldo ${ }^{c}$ \\ Marilda Mazzalic Marlene Antonia dos Reis ${ }^{d}$ Vicente de Paula Antunes Teixeira ${ }^{d}$ \\ Alvaro Pacheco-Silva ${ }^{a, e}$ Luis Eugênio A. de Mellob Niels O.S. Câmara ${ }^{a}{ }^{\mathrm{f}}$

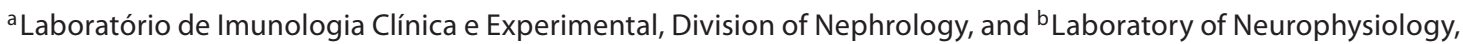 \\ Division of Physiology, Universidade Federal de São Paulo, São Paulo, 'Division of Nephrology, Universidade \\ Estadual de Campinas, Campinas, ${ }^{d}$ Division of Pathology, Universidade Federal do Triângulo Mineiro, Minas \\ Gerais, ${ }^{e}$ Instituto Israelita de Ensino e Pesquisa Albert Einstein, São Paulo, and ${ }^{\mathrm{f}}$ Laboratory of Transplantation \\ Immunobiology, Department of Immunology, Universidade de São Paulo, São Paulo, Brazil
}

\section{Key Words}

Neurospheres $\cdot$ Neural precursor cells $\cdot$ Ischemia and reperfusion injury, renal $\cdot$ Immunomodulation

\begin{abstract}
In this study we evaluated whether administration of stem cells of neural origin (neural precursor cells, NPCs) could be protective against renal ischemia-reperfusion injury (IRI). We hypothesized that stem cell outcomes are not tissue-specific and that NPCs can improve tissue damage through paracrine mechanisms, especially due to immunomodulation. To this end, Wistar rats (200-250 g) were submitted to 1-hour ischemia and treated with NPCs $\left(4 \times 10^{6}\right.$ cells/animal) at $4 \mathrm{~h}$ of reperfusion. To serve as controls, ischemic animals were treated with cerebellum homogenate harvested from adult rat brain. All groups were sacrificed at $24 \mathrm{~h}$ of reperfusion. NPCs were isolated from rat fetus telencephalon and cultured until neurosphere formation (7 days). Before administration, NPCs were labeled with carboxyfluorescein diace-
\end{abstract}

tate succinimydylester (CFSE). Kidneys were harvested for analysis of cytokine profile and macrophage infiltration. At $24 \mathrm{~h}, \mathrm{NPC}$ treatment resulted in a significant reduction in serum creatinine (IRI + NPC $1.21+0.18$ vs. IRI $3.33+0.14$ and IRI + cerebellum $2.95+0.78 \mathrm{mg} / \mathrm{dl}, \mathrm{p}<0.05)$ and acute tubular necrosis (IRI + NPC $46.0+2.4 \%$ vs. IRI $79.7+14.2 \%, p<$ $0.05)$. NPC-CFSE and glial fibrillary acidic protein (GFAP)-positive cells (astrocyte marker) were found exclusively in renal parenchyma, which also presented GFAP and SOX-2 (an embryonic neural stem cell marker) mRNA expression. NPC treatment resulted in lower renal proinflammatory IL1- $\beta$ and TNF- $\alpha$ expression and higher anti-inflammatory IL-4 and IL10 transcription. NPC-treated animals also had less macrophage infiltration and decreased serum proinflammatory cytokines (IL-1 $\beta$, TNF- $\alpha$ and INF- $\gamma$ ). Our data suggested that NPC therapy improved renal function by influencing immunological responses.

\section{KARGER}

Fax +4161306 1234 E-Mail karger@karger.ch www.karger.com
(C) 2009 S. Karger AG, Basel

$1660-2129 / 09 / 1121-0020 \$ 26.00 / 0$

Accessible online at:

www.karger.com/nee
Niels Olsen Saraiva Câmara

Department of Immunology, Institute of Biomedical Science

Universidade de São Paulo, USP, Rua Prof Lineu Prestes, 1730

05508-900 São Paulo, SP (Brazil)

Tel. +55 113091 7388, Fax +55 113091 7224, E-Mail niels@icb.usp.br 


\section{Introduction}

Acute renal failure (ARF) mainly develops following ischemic or toxic insults, whereby damage is not only caused by loss of blood regulation, but also by production and regulation of multiple cytokines [1]. Development of improved therapies able to limit this immunological response can have a relevant impact on ARF. This quest extends to a new field of research, the stem cell therapy studies. However, full comprehension of the mechanisms underlying stem cell therapy has yet to be achieved, although it has been hypothesized that these may act through dedifferentiation, paracrine modulation or cell fusion [2-4]. In renal insults, consensus data rely on more beneficial effects after mesenchymal stem cell administration and action through inflammatory modulation [5].

Furthermore, stem-cell plasticity is remarkable. Mesenchymal stem cell, once believed necessary for hematopoietic stem cell support, are now known to differentiate into several tissues, including neural cells [6]. Their broad plasticity may determine their therapeutic potential. We believe that stem cell benefits are not tissue-specific and have hypothesized that stem cells of neural origin could be protective against a renal insult, chiefly through paracrine mechanisms.

A direct link between neural molecules and renoprotection is being discovered. Growth and transcription factors similar to those essential to the nervous system may be operating in the kidney and be induced after stimuli, such as an ischemic episode [7]. Moreover, exogenous administration of glial cell line-derived neurotrophic growth factor was shown to be protective against renal IRI [8].

In this study, we analyzed whether neural precursor cells (NPCs) could be protective against renal IRI. NPCs are grown in suspension, giving rise to cell aggregates also known as neurospheres. NPCs represent both neural stem cells and neural progenitor cells that coexist within neurospheres [9]. Within the neurospheres, the neural stem cells are able to self-renew and after asymmetrical divisions can give rise to neural progenitors [10]. The neural progenitor cells are more restricted to glial or neuronal lineage and have reduced self-renewal capability. Thus, neurospheres are heterogeneous cell aggregates of precursor cells in a wide range of differentiation and commitment stages. We had previously observed that within rat neurospheres, approximately $25 \%$ of the cells were $\beta$-tubulin III-positive (neurons or neuronal progenitors) and $20 \%$ glial fibrillary acidic protein (GFAP)-pos- itive (astrocytes or glial progenitors) [11]. We also showed that only $30 \%$ of the cells were nestin-positive (neural stem cells). Nestin expression cannot be found in $100 \%$ of cells because its expression is downregulated upon differentiation. To observe the differentiation capability of neurospheres, they have to be plated on a substrate that allows adhesion and migration in the absence of mitogens. In this condition, neurospheres spontaneously give rise to functional neurons, astrocyes and oligodendrocytes [12-14].

Because neurospheres produce growth factors [15] and cytokines [16-19], they can also modify tissue immune responses. Our hypothesis is that NPC administration can improve renal IRI by immunomodulation. We believe that this process is not tissue-specific and depends on paracrine mechanisms. Herein, we found that NPC treatment improved renal function after IRI, mainly due to polarization of the immune response into an anti-inflammatory pattern.

\section{Methods}

Animals

Male Wistar rats (220-250 g) were purchased from the Center of Development of Experimental Models for Biology (CEDEME - UNIFESP), São Paulo, Brazil. All procedures were previously reviewed and approved by the internal Ethics Committee on Animal Research of the Universidade Federal de São Paulo (UNIFESP).

Harvesting and Culturing Rat NPCs

NPCs were obtained from Wistar rat fetuses 14.5 days postconception (embryonic day 14.5), as previously described [20]. Briefly, telencephalons were dissected and incubated with trypsin-EDTA solution (Gibco, Paisley, UK) for $10 \mathrm{~min}$ at $37^{\circ} \mathrm{C}$. Cells were dissociated and filtered in a $40-\mu \mathrm{m}$ cell strainer (BD Bioscience, San Jose, Calif., USA). The culture media contained 70\% DMEM, 30\% F12, 1\% PSA, 2\% B27 (Gibco), 20 ng/ml EGF (Sigma, St. Louis, Mo., USA), $20 \mathrm{ng} / \mathrm{ml}$ FGF-2 (R\&D, Abingdon, UK), and $5 \mu \mathrm{g} / \mathrm{ml}$ heparin (Sigma). Cells were seeded in T25 flasks (100,000 cells $/ \mathrm{ml}$ ) and maintained at $37^{\circ} \mathrm{C}$ in a $5 \% \mathrm{CO}_{2}$ atmosphere. Neurospheres were cultured for 10-14 days before administration.

\section{In vitro Differentiation Studies}

For NPC plating, coverslips were coated with poly-L-lysine $(0.1 \mathrm{mg} / \mathrm{ml}$ in water) and laminin solution $(50 \mu \mathrm{g} / \mathrm{ml}$ in PBS; Sig$\mathrm{ma})$ at $37^{\circ} \mathrm{C}$ for $30 \mathrm{~min}$. Spheres were then plated in a differentiation medium containing 70\% DMEM, 30\% F12 and 2\% B27. During a 7-day period the cells that migrated from the neurospheres spontaneously differentiated into neurons, astrocytes and oligodendrocytes. Cells were fixed in 4\% PFA and permeabilized in PBS $0.1 \mathrm{M} / 5 \%$ goat serum $/ 0.1 \%$ Triton $\mathrm{X}-100$. They were then incubated overnight at $4{ }^{\circ} \mathrm{C}$ with primary antibodies against $\beta$-tubulin III (mouse IgG2b, 1:200; Sigma) to visualize neurons, GFAP (rabbit IgG, 1:300; DakoCytomation, Glostrup, Denmark) for as- 
trocytes and Galactocerebroside-C (Gal-C; mouse IgG, 1:200; Chemicon, Oxfordshire, UK), an oligodendrocyte marker. Secondary antibodies Alexa 546 or Alexa 488 (Molecular Probes, Eugene, Oreg., USA) were used. Cells were viewed under a fluorescence microscope (Nikon, Tokyo, Japan).

\section{Experimental Model of Renal IRI}

Surgery was performed as previously described [21]. Rats were anesthetized with ketamine-xylazine (Agribrands do Brazil, São Paulo, Brazil). Renal pedicles were cross-clamped for $1 \mathrm{~h}$. During this time animals were kept well hydrated and at a constant temperature $\left(\sim 37^{\circ} \mathrm{C}\right)$. After surgery, animals were placed in single cages and warmed by indirect light until complete recovery from anesthesia. Animals were kept under adjustable conditions until sacrifice at $24 \mathrm{~h}$ of reperfusion. Control animals were subjected to the surgical procedure without renal vessel occlusion (sham).

\section{NPC Administration}

Prior to administration, neurospheres growing in suspension were disrupted by trypsin-EDTA in order to form single cell suspensions. Cell viability was tested by trypan blue and propidium iodide. The percentage of viable cells was always superior to $90 \%$. Only viable cells were consider to determine the final cell density used for treatment. Approximately $4 \times 10^{6}$ of NPCs in single suspension were given to each animal $4 \mathrm{~h}$ after the insult. Initially, several administration routes were tested (intravenous, i.v., intraperitoneal, i.p., and intracortical, i.c.). After this, all treatments used the i.v. route. To act as controls some animals were treated with adult rat cerebellum homogenate, known to be a stem cellfree zone [22-24]. NPCs and cerebellum cells were labeled with $3 \mu \mathrm{M}$ carboxyfluorescein diacetate succimydylester (CFSE) in constant agitation for $30 \mathrm{~min}$ at $37^{\circ} \mathrm{C}$, before administration.

\section{Animals Groups}

Animals were assigned as follows: group $1($ IRI, $\mathrm{n}=10)=$ animals subjected to IRI; group 2 (IRI + NPC, $\mathrm{n}=10)$ = animals subjected to IRI and treated with NPCs; group 3 (IRI + cerebellum, $\mathrm{n}=10)=$ animals subjected to IRI and treated with cerebellum cells isolated from adult rat brain; group $4(\mathrm{n}=10)=$ sham-operated animals, and group $5(\mathrm{n}=10)=$ sham-operated animals treated with NPCs. Surgeries were performed as follows: groups 1-3 underwent surgical procedures on the same day, and groups 4 and 5 the next day (2 animals/group).

\section{Renal Function}

Serum creatinine was measured to evaluate renal function. Blood samples were collected at 0, 4 and $24 \mathrm{~h}$ from the vascular plexus. At $4 \mathrm{~h}$, blood was collected immediately before NPC treatment. Serum creatinine was measured on a Cobas Mira Plus (Roche, Mannheim, Germany), using the modified Jaffé technique, as previously described [21].

\section{Histological Morphometric Analyses}

Kidney formaldehyde-fixed paraffin sections were stained with hematoxylin and eosin. The extent of acute tubular necrosis (ATN) morphology in the outer medulla was examined by blinded morphometric assessment using a computer-assisted imaging system with an Olympus BX40F-3 microscope (Olympus Optical Company, Tokyo, Japan) and the software program KS300 (Zeiss, Thornwood, N.Y., USA). The results are expressed as a ratio of the injured area to total area $\left(145,846.7 \mu \mathrm{m}^{2}\right)$. Twenty-five random fields were counted at an original magnification $\times 835$, almost covering all outer medulla, corresponding to an area of 3,646,167.5 $\mu \mathrm{m}^{2}$, for each animal, per slide. For morphometric analyses, ATN was analyzed $24 \mathrm{~h}$ after reperfusion. Tubular necrosis pattern included: loss of cytoplasmatic and nuclear membrane integrity, loss of brush border, vacuolization of tubular epithelial cells, and presence of intratubular debris.

\section{Immunohistochemistry}

Immunohistochemistry was performed using the $\mathrm{ABC}$ method.

GFAP marker: Kidney sections were incubated overnight with primary polyclonal antibody against GFAP (1:500; DakoCytomation) followed by incubation with secondary biotinylated antirabbit antibody (from donkey, 1:100; Amersham Biosciences, Buckinghamshire, UK) and streptavidin-HRP for $2 \mathrm{~h}$ each (BD Bioscience). Cultured NPCs differentiated into astrocyte (GFAPpositive cells), and adult rat brain sections (data not shown) were used as positive controls

ED-1 marker: Slides were incubated with primary ED-1 antibody (Serotec, Oxford, UK), followed by incubation with the specific biotinylated secondary antibody. Macrophages were counted in 15 random cortical and 10 medullar tubule-interstitial HPFs $(\times 400)$. The HPFs $(\times 400)$ were grid-lined $(10 \times 10)$, and the number of stained grid fields was counted in each HPF using the KS 300 Imaging System (Carl Zeiss Microimaging, Jena, Germany). The results are expressed as the percentage of positive fields at the cortex and medulla.

\section{RT-PCR}

Kidney samples were quickly frozen in liquid nitrogen. Total RNA was isolated by the TRIzol Reagent (Invitrogen, Carlsbad, Calif., USA) methodology, and first-strand cDNA was synthesized by MML-V reverse transcriptase (Promega, Wisc., USA), according to the manufacturer's protocol. RT-PCR was performed for GFAP (sense) 5'-AAG AGT GGT ATC GGT CCA AGT TTG3', (anti-sense) 5'-CAG TTG GCG GCG ATA GTC AT-3' and SOX-2 (sense) 5'-GTC AAG AGG CCC ATG AAT GC-3', (antisense) 5'-TCT CGG TCT CCG ACA AAA GTT T-3'. The housekeeper gene hypoxanthine guanine phosphoribosyltransferase (HPRT; sense) 5'-CTC ATG GAC TGA TTA TGG ACA GGA C-3' and (anti-sense) $5^{\prime}$-GCA GGT CAG CAA AGA ACT TAT AGC C- $3^{\prime}$ was used as endogenous control. Cycling conditions were: 10 min at $95^{\circ} \mathrm{C}$ followed by 40 cycles of $30 \mathrm{~s}$ at $95^{\circ} \mathrm{C}, 30 \mathrm{~s}$ at $58^{\circ} \mathrm{C}$ and $30 \mathrm{~s}$ at $72^{\circ} \mathrm{C}$. Resulting fragments were analyzed in a $2.0 \%$ agarose gel electrophoresis. For this assay, cultured neural stem cells and adult rat brain were used as controls.

\section{Flow Cytometry}

Kidney, lung, spleen and liver were harvested at $24 \mathrm{~h}$, homogenated and filtered by a $0.45-\mu \mathrm{m}$ filter. Blood was also collected at $24 \mathrm{~h}$. We used cultured NPCs labeled and non-labeled with CFSE and organs harvested from the sham and non-treated ischemic group as controls. $3.5 \mathrm{ml}$ of FACS buffer was added to each sample. Then, samples were centrifuged at $1,400 \mathrm{rpm}$ for $10 \mathrm{~min}$ at $4^{\circ} \mathrm{C}$, the supernatant was removed and pellets resuspended in $4 \mathrm{ml}$ of FACS buffer. The samples were analyzed in the FACSCanto (Beckton Dickson, Mountain View, Calif., USA) cytometer with the aid of Cell Quest software. 

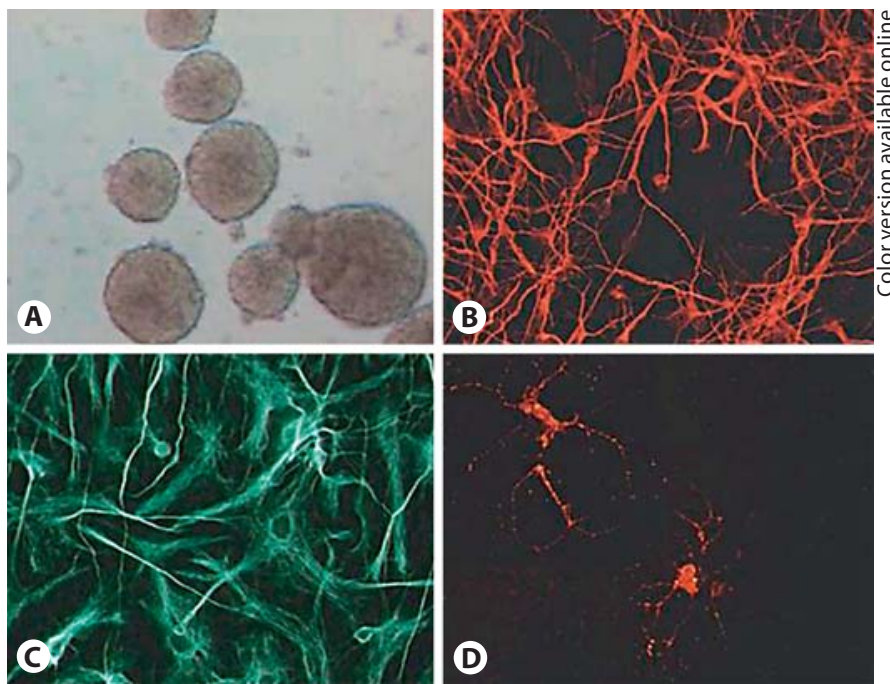

Fig. 1. NPC differentiation. NPCs were grown in suspension and gave rise to cell aggregates called neurospheres $(\mathbf{A})$. For differentiation, NPCs were plated on coverslips coated with poly-L-lysine $(0.1 \mathrm{mg} / \mathrm{ml}$ in water) and laminin solution $(50 \mu \mathrm{g} / \mathrm{ml}$ in PBS; Sig$\mathrm{ma}, \mathrm{USA})$ at $37^{\circ} \mathrm{C}$ for $30 \mathrm{~min}$ and cultivated in a differentiation medium containing 70\% DMEM, 30\% F12 and 2\% B27, for 7 days. During this period the migrating cells spontaneously differentiated into neurons, astrocytes and oligodendrocytes. Detection of differentiated cells was made by immunofluorescence. Cells were fixed in $4 \%$ PFA and permeabilized in PBS $0.1 \mathrm{M} / 5 \%$ goat serum $/ 0.1 \%$ Triton $X-100$. They were then incubated with primary antibodies against $\beta$-tubulin III (mouse IgG2b, 1:200) for neurons (B), GFAP (rabbit IgG, 1:300) for astrocytes (C), and Gal-C (mouse IgG, 1:200) for oligodendrocytes (D). Secondary antibodies Alexa 546 or Alexa 488 (Molecular Probes) were used.

\section{Cytokine $\mathrm{mRNA}$}

Real-time PCR was performed using the following TaqMan PCR assays: IL-1 $\beta$ (Mm00434228_m1), IL-4 (Mm00445259_m1), IL-10 (Mm00439616_m1), TNF- $\alpha$ (Mm00443258_m1), and the housekeeper gene HPRT (Mm00446968_m1; Applied Biosystems, Foster City, Calif., USA). We used the cycling conditions described by the manufacturer (Applied Biosystems). mRNA relative quantification was performed using the comparative threshold method (described in details in User Bulletin 2; PerkinElmer, Applied Biosystems, Foster City, Calif., USA, 1997). The target gene amount was normalized by HPRT and then compared to a calibrator (non-treated sham-operated animals) using the formula $2^{-\Delta \Delta \mathrm{Ct}}$. All data were expressed as an $\mathrm{n}$-fold difference related to the expression of matched controls (sham). Analyses were performed with Sequence Detection Software 1.9 (SDS).

\section{ELISA}

Cytokine were measured in serum collected at $24 \mathrm{~h}$ of reperfusion using custom BioRad (Bio-Rad Laboratories, Hercules, Calif., USA) BioPlex cytokine analysis kits in conjunction with the BioPlex system array reader, according to the manufacturer's instructions. The specific cytokines (IL-1 $\beta$, TNF- $\alpha$ and IFN- $\gamma$ )

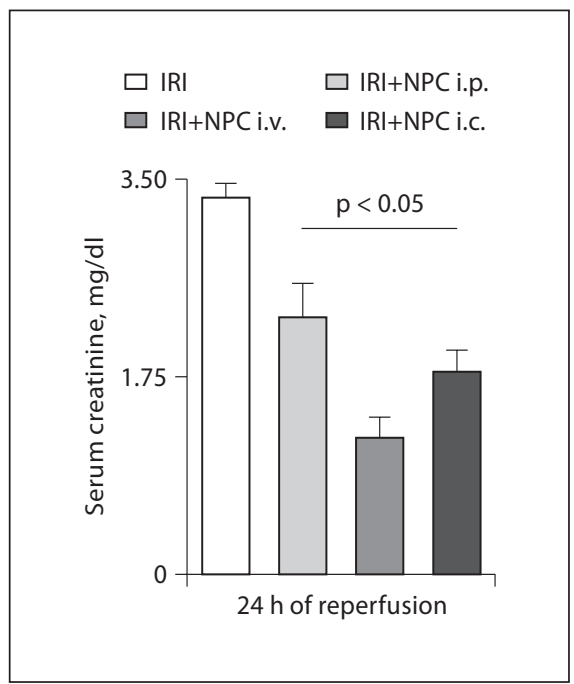

Fig. 2. Different routes of NPC administration. Intraperitoneal, intravenous and intracortical administrations were tested. All NPC administration routes reduced serum creatinine levels at $24 \mathrm{~h}$ of reperfusion.

were chosen based on our PCR data to be representative of injury in ischemia. Samples were run in triplicate in each assay. Standard curves for each of the analyzed substances were included in each run, and sample concentrations were calculated using BioPlex Manager software.

\section{Statistical Analyses}

All data are described as mean + SEM. Different results among groups were compared using the ANOVA. Significance was considered when $\mathrm{p}<0.05$. All statistical analyses were performed with the aid of SigmaStat Statistical Software 2.0 (Jandel Corporation, Tex., USA).

\section{Results}

\section{NPC Treatment}

Before treatment, NPC plasticity was observed through in vitro differentiation into neurons and astrocytes (fig. 1). For treatment, several administration routes were tested. All administration routes presented a significant reduction in serum creatinine levels (i.p. $2.28+0.30 \mathrm{mg} /$ dl; i.v. $1.21+0.18 \mathrm{mg} / \mathrm{dl}$, and i.c. $1.79+0.20 \mathrm{mg} / \mathrm{dl}$ vs. IRI $3.33+0.14 \mathrm{mg} / \mathrm{dl}, \mathrm{p}<0.05$; fig. 2). The i.v. administration was chosen for all of the following assays. No difference between sham and sham $+\mathrm{NPC}$ creatinine levels was observed at $24 \mathrm{~h}$ of reperfusion (sham $+\mathrm{NPC} 0.53+0.08 \mathrm{mg} /$ $\mathrm{dl}$, and sham $0.63+0.09, \mathrm{p}<0.05)$. 


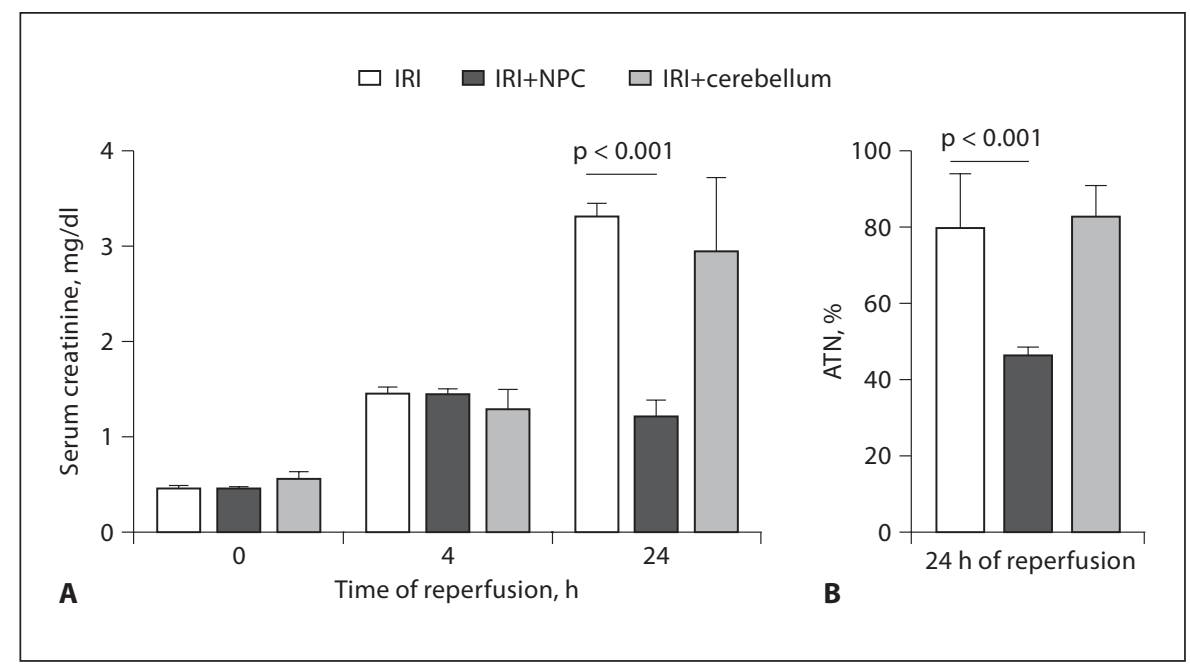

Fig. 3. Tissue response after NPC administration. Renal function at different reperfusion times was estimated by serum creatinine levels (A). At $4 \mathrm{~h}$ of reperfusion, and immediately before NPC or cerebellum cell administration, all ischemic groups had similar serum creatinine levels. However, at $24 \mathrm{~h}$ of reperfusion, only the NPC-treated group presented a significant reduction in this parameter. Renal function results were corroborated by histological analyses of renal parenchyma collected at $24 \mathrm{~h}$ of reperfusion (B). The extension of acute tubular necrosis (ATN) morphology in the outer medulla was examined by blinded morphometric assess- ment using an Olympus BX40F-3 microscope (Olympus Optical Company) and KS300 software program (Zeiss, Thornwood, N.Y., USA). The results are expressed as a ratio of the injured area versus total area $\left(145,846.7 \mu \mathrm{m}^{2}\right)$. The tubular necrosis pattern included: loss of cytoplasmatic and nuclear membranes integrity, loss of brush border, vacuolization of tubular epithelial cells, and presence of intratubular debris. The IRI+NPC group had a lower percentage of ATN. No difference was observed between IRI and IRI+cerebellum groups concerning serum creatinine levels or percentage of ATN.

\section{Renal Function}

Immediately before treatment ( $4 \mathrm{~h}$ of reperfusion), all groups subjected to renal IRI had similar serum creatinine levels (IRI $1.46+0.07 \mathrm{mg} / \mathrm{dl}$, IRI+NPC $1.44+0.07$ $\mathrm{mg} / \mathrm{dl}$ and IRI+cerebellum cells $1.30+0.20 \mathrm{mg} / \mathrm{dl}$; fig. 3 ). At $24 \mathrm{~h}$, only the IRI+NPC-treated group presented a significant reduction in serum creatinine in comparison to the other ischemic groups (IRI+NPC $1.21+0.18$ vs. IRI $3.33+0.14$ and IRI+cerebellum $2.95+0.78 \mathrm{mg} / \mathrm{dl}, \mathrm{p}<$ 0.05 ; fig. 3A).

The better renal function of the IRI+NPC rats was corroborated by their lower percentage of ATN assayed by morphometric analyses after hematoxylin-eosin staining (IRI+NPC $46.0+2.4 \%$ vs. IRI $79.7+14.2 \%$ and IRI+cerebellum cells $78.9+12.5 \%, \mathrm{p}<0.05$; fig. $3 \mathrm{~B})$.

\section{NPC Intrarenal Localization after Treatment}

Different techniques were used to demonstrate NPC migration and survival in ischemic kidneys. All assays were performed in kidneys collected at $24 \mathrm{~h}$. Immunohistochemistry against GFAP had positive staining only in ischemic kidneys from the NPC-treated group (fig. 4A). Sham-operated animals treated with NPC, non-treated
IRI group and ischemic animals treated with cerebellum cells had no GFAP or other neural marker-positive staining (data not shown). GFAP is a marker of astrocytes or glial progenitors, thus it was able to identify NPCs in a latter differentiation stage. The presence of SOX-2 and GFAP mRNA was also observed exclusively in the IRI NPC-treated group (fig. 4B). SOX-2 is an embryonic neural stem cell marker and its positive expression in kidney homogenates indicated that NPCs at the beginning of their differentiation also migrated to the injured kidneys.

To analyze the approximately number of NPCs that were able to migrate to the ischemic kidneys we treated the rats with NPC-CFSE-positive cells and estimated their migration by flow cytometry. CFSE is a fluorescent staining dye that labeled all NPCs regardless of their differentiation. After NPC treatment, flow cytometry revealed 6.94\% NPC-CFSE-positive cells in kidney extracts (fig. 4C). At $24 \mathrm{~h}$, no NPC-CFSE-positive cells were observed in blood, spleen or liver. In lungs, $0.99 \%$ of the cells were CFSE-positive, while in the liver $0.04 \%$ were positive. Since these values were very low they were considered equal to zero (data not shown). 


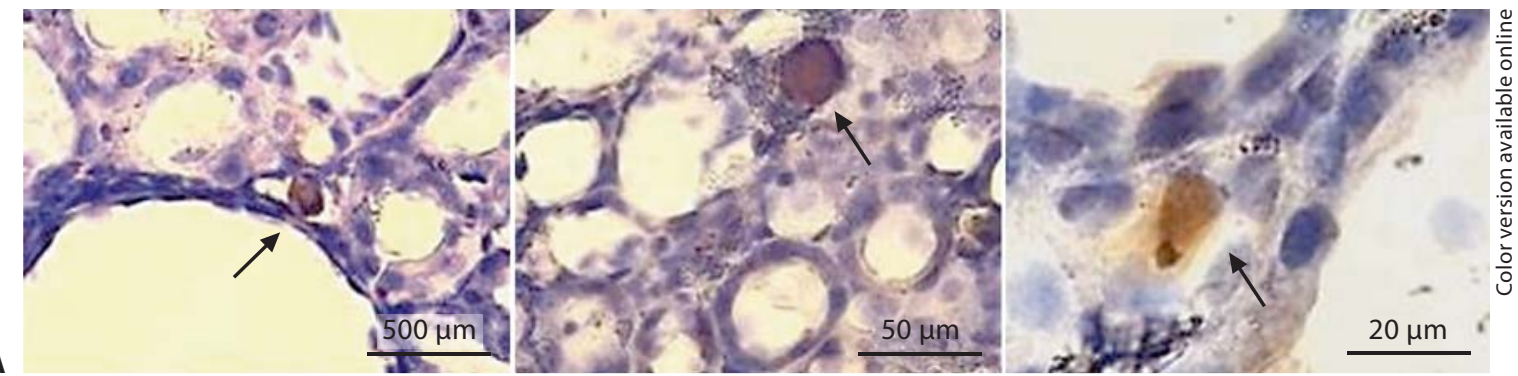

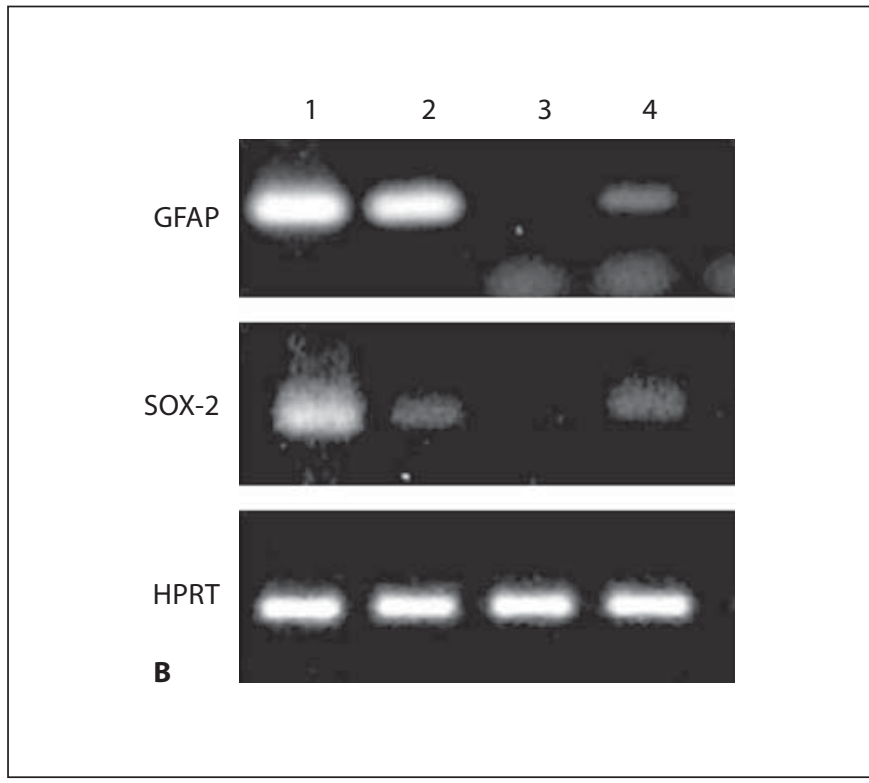

Fig. 4. NPC homing to ischemic kidneys. Kidneys were collected at $24 \mathrm{~h}$ of reperfusion. Immunohistochemistry found GFAP-positive cells (indicated by arrows) only in the NPC+IRI group (A). NPC genes were observed in renal parenchyma by RT-PCR. For this assay, cultured NPCs were used as control. SOX-2 (embryonic neural stem cell marker) and GFAP mRNA expression were only observed in the NPC-treated group (B). Lane $1=$ Cultured

\section{Cytokine Profile}

We analyzed whether NPC treatment could induce an anti-inflammatory pattern. Cytokine mRNA was measured in kidney homogenate by RT-PCR. The IRI+NPC group had significantly lower renal expression of IL-1 $\beta$ and TNF- $\alpha$, and higher transcription of IL- 4 and IL-10, in comparison to the other ischemic groups (fig. 5). Sham and sham+NPC groups had similar values which differed from all ischemic groups (data not shown). Similarly, no difference was observed between IRI and IRI+cerebellum groups.

Furthermore, we measured the expression of some proinflammatory cytokines in serum collected at $24 \mathrm{~h}$ of

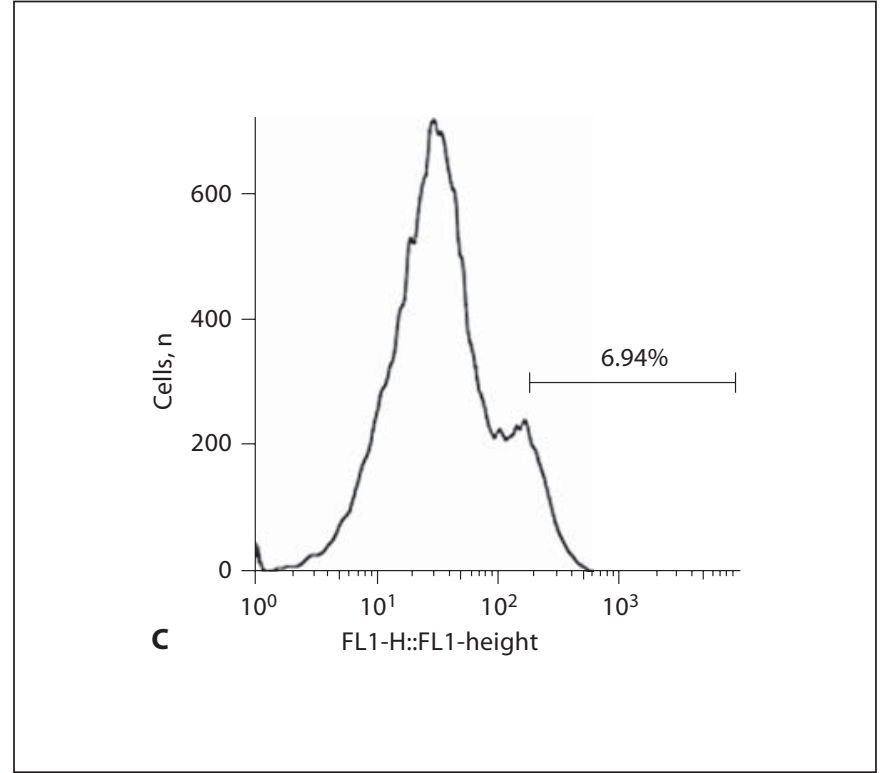

NPC; lane 2 = adult rat brain; lane $3=$ IRI, and lane $4=I R I+N P C$. After NPC-CFSE administration, flow cytometry demonstrated $6.94 \%$ CFSE-positive cells in renal extracts collected at $24 \mathrm{~h}$ of reperfusion (C). No NPC-CFSE-positive cells were observed in blood, spleen or liver. In lungs, $0.99 \%$ of the cells were CFSE-positive, while in the liver $0.04 \%$ were positive (data not shown). Since these values were very low, they were considered equal to zero. 

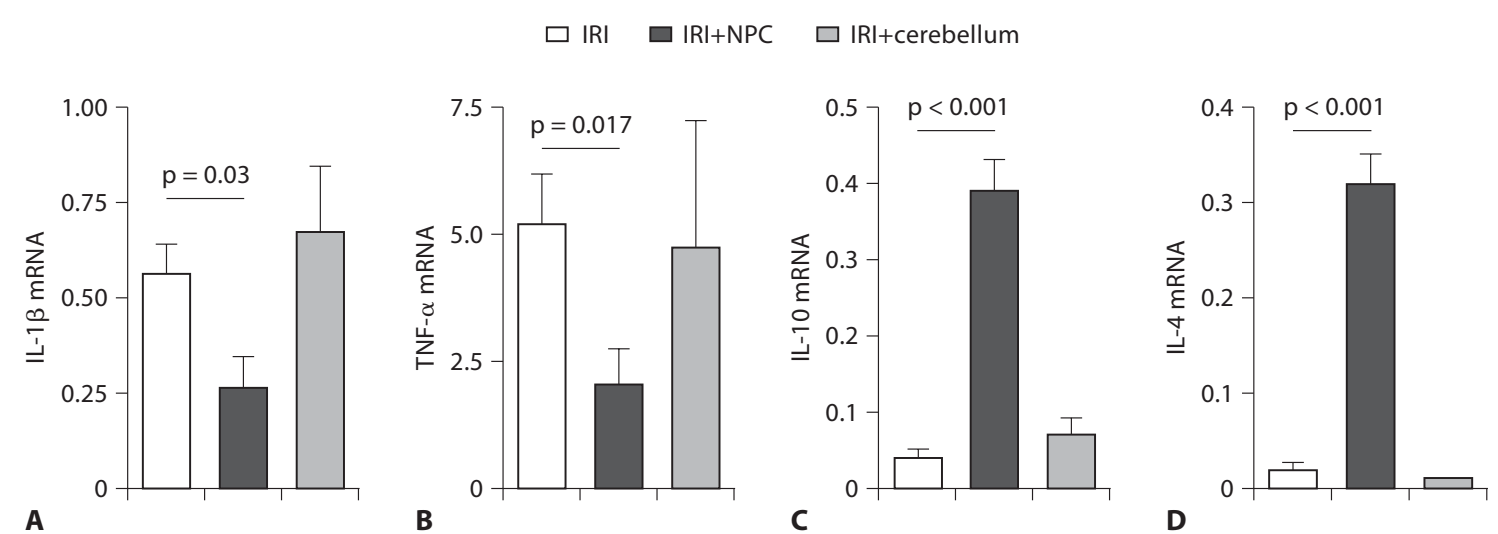

Fig. 5. Renal cytokine expression. Cytokine profile was measured by real-time PCR. The proinflammatory pattern was assayed by IL- $1 \beta$ and TNF- $\alpha$ expression, and the anti-inflammatory pattern by IL-4 and IL-10. NPC treatment significantly reduced IL-1 $\beta$ (A)

and TNF- $\alpha$ (B) expression and increased IL-10 (C) and IL-4 (D) transcription observed in the ischemic non-treated and ischemic treated with cerebellum cell groups. No difference was observed between IRI and IRI+cerebellum groups.
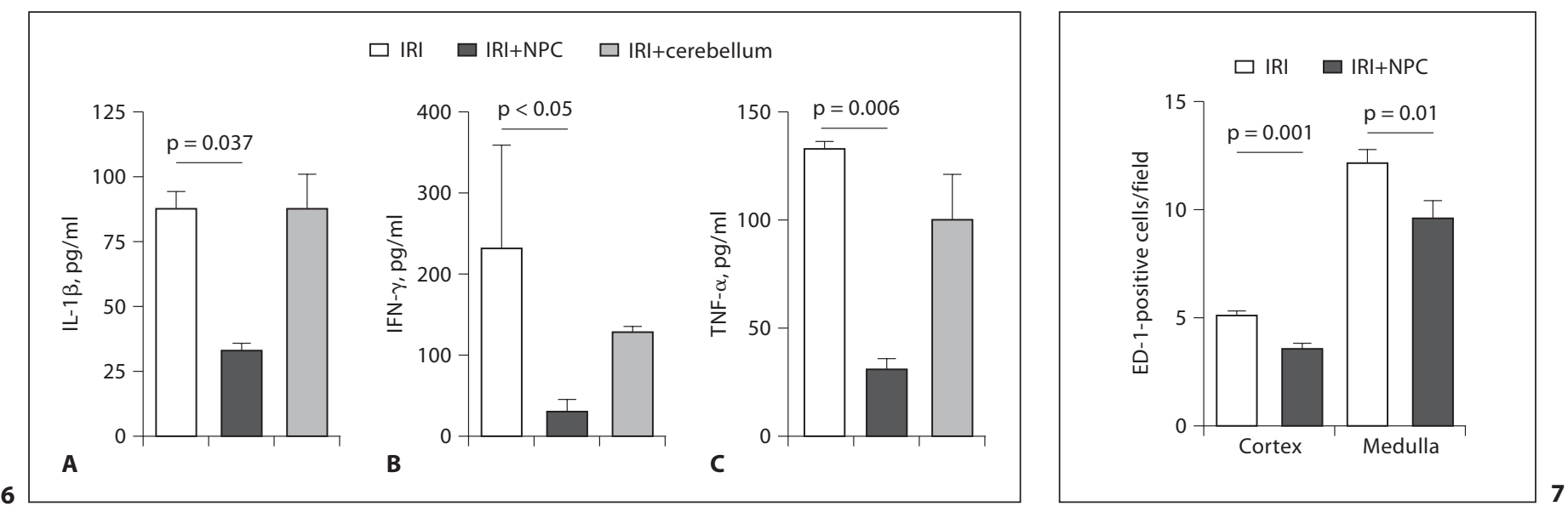

Fig. 6. Circulatory cytokine expression. Cytokines were measured in serum collected at $24 \mathrm{~h}$ of reperfusion using custom ELISA BioPlex cytokine analysis. The specific cytokines IL-1 $\beta$, TNF$\alpha$ and IFN- $\gamma$ were chosen based on our PCR data to be representative of injury in ischemia. Samples were run in triplicate in each assay. Standard curves for each of the analyzed substances were included in each run, and sample concentrations were calculated using BioPlex Manager Software. NPC treatment significantly reduced the circulatory levels of IL-1 $\beta$, INF- $\gamma$ and TNF- $\alpha$. No difference was observed between IRI and IRI+cerebellum groups. Sham-operated animals presented values close to the detection limit of the test (data not shown). NSC = Neural stem cell.

Fig. 7. Macrophage infiltration. Kidney samples harvested at $24 \mathrm{~h}$ after reperfusion were analyzed for macrophage infiltration. Slides were incubated with primary antibody ED-1 (Serotec), followed by incubation with the specific biotinylated secondary antibody. Reaction was continued using an ABC detection kit (Dako, Glostrup, Denmark) and diaminobenzidine tetrahydrochloride color developer (Dako, Carpinteria, Calif., USA). Macrophages were counted in 15 random cortical and 10 medullar tubule-interstitial HPFs $(\times 400)$. The HPFs $(\times 400)$ were grid-lined $(10 \times$ 10 ), and the number of stained grid fields was counted in each HPF using the KS 300 Imaging System (Carl Zeiss Microimaging, Jena, Germany). Results are expressed as percentage of positive fields in the cortex and medulla. NPC treatment significantly reduced macrophage infiltration in the renal cortex and medulla. 


\section{Discussion}

IRI is one of the main causes of ARF, and new therapies to ameliorate this injury are extremely important. In this vein, stem cell therapy is gaining increased attention.

In cerebral ischemia, NPC protection has been attributed to maximum trophic factor activation, which probably augmented NPC migration in positive feedback [25]. Thus, a reciprocal interaction between NPCs and the ischemic environment may be crucial for its protective action. However, little is known on how NPCs work. The present study demonstrates that in renal ischemia, NPC administration can be beneficial. It was observed that NPC treatment reduced serum creatinine and morphological damage. To our knowledge, this study was the first attempt to show that protection may not be tissue-specific.

Stem cell therapeutic potential also relies on homing ability to injured sites, which may depend on chemotactic properties, probably through chemokine, selectin or integrin interactions in a similar process or manner to that of leukocytes [26]. We demonstrated that NPCs migrated and survived exclusively in ischemic kidneys until sacrifice at $24 \mathrm{~h}$. On the other hand, fully differentiated cells derived from adult cerebellum were not able to migrate to the injury site and did not promote any improvement in renal function. We believe that inflammation represents the key danger signal for orchestrating recruitment and long-term survival of NPCs.

Stem cell benefits are also associated with immune response suppression through modulation of T cells [27], B cells [28], NK cells [29] and antigen-presenting cell [30] functions. In this manner, paracrine modulation has become increasingly plausible. In renal IRI, an inflamma- tory syndrome is present, and TCD4+ lymphocytes have been identified as major immunological effectors of this pathology [31]. Renoprotective responses are achieved after Th2 differentiation [32]. Renal protection was found after Th1 component deletion and deleterious effects in the absence of Th2 molecules [33]. The Th1 pattern is triggered by Tbet transcription factor activation and IL12 , IL-1 $\beta$ and IFN- $\gamma$ production. Meanwhile, the Th2 pattern is characterized by activation of the transcription factor GATA-3 followed by IL-4, IL-5, IL-6, IL-10 and IL13 production. In this study, NPC treatment increased anti-inflammatory molecule expression (IL-4 and IL-10) and significantly diminished the proinflammatory IL-1 $\beta$ and TNF- $\alpha$ renal transcription and IL- $1 \beta$, INF- $\gamma$ and TNF- $\alpha$ circulatory levels. Thus, NPC treatment was able to modify the immune response found in renal IRI, unbalancing it to an Th2 pattern which is protective against renal IRI [32, 34]. NPC immune modulation properties have also been shown in experimental models of nervous system disorders [35] and in vitro [16-19].

Although we were unable to describe all processes involved in NPC protection, their ability to remain in the ischemic kidney and protect against the insult was remarkable, indicating that there is a lot more to learn about stem cell plasticity.

\section{Acknowledgements}

We are grateful to Milton Ginoza, Henrique Thiago Andreucci and Marcos Antonio Cenedeze for all the technical assistance in the development of this study.

This work was supported by MCT/CT-Saúde/Decit/SCTIE/ MS, grant No. 552307/2005-0, and Fundação de Apoio à Pesquisa do Estado de São Paulo, grant Nos. 04/08311-6, 04/13826-5, 05/50085-6 and 07/07139-3.

\section{References}

1 Lieberthal W, Nigam SK: Acute renal failure II. Experimental models of acute renal failure: imperfect but indispensable. Am Physiol Renal Physiol 2000;278:F1-F12.

-2 Prockop DJ, Gregory CA, Spees JL: One strategy for cell and gene therapy: harnessing the power of adult stem cells to repair tissues. Proc Natl Acad Sci USA 2003;100(suppl 1):11917-11923

Neural Precursor Cells and Renal IRI
3 Terada N, Hamazaki T, Oka M, Hoki M, Mastalerz DM, Nakano Y, Meyer EM, Morel L, Petersen BE, Scott EW: Bone marrow cells adopt the phenotype of other cells by spontaneous cell fusion. Nature 2002;416:542545.

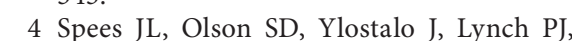
Smith J, Perry A, Peister A, Wang MY, Prockop DJ: Differentiation, cell fusion, and nuclear fusion during ex vivo repair of epithelium by human adult stem cells from bone marrow stroma. Proc Natl Acad Sci USA 2003; 100:2397-2402.
5 Togel F, Hu Z, Weiss K, Isaac J, Lange C, Westenfelder C: Administered mesenchymal stem cells protect against ischemic acute renal failure through differentiation-independent mechanisms. Am J Physiol Renal Physiol 2005;289:F31-F42.

-6 Azizi SA, Stokes D, Augelli BJ, DiGirolamo C, Prockop DJ: Engraftment and migration of human bone marrow stromal cells implanted in the brains of albino rats - similarities to astrocyte grafts. Proc Natl Acad Sci USA 1998;95:3908-3913. 
7 Orth SR, Ritz E, Suter-Crazzolara C: Glial cellline-derived neurotrophicfactor (GDNF) is expressed in the human kidney and is a growth factor for human mesangial cells. Nephrol Dial Transplant 2000;15:589-595.

8 Shi H, Patschan D, Dietz GP, Bähr M, Plotkin M, Goligorsky MS: Glial cell line-derived neurotrophic growth factor increases motility and survival of cultured mesenchymal stem cells and ameliorates acute kidney injury. Am J Physiol Renal Physiol 2008;294: F229-F235.

-9 Gage FH, Ray J, Fisher LJ: Isolation, characterization, and use of stem cells from the CNS. Annu Rev Neurosci 1995;18:159-192.

-10 Svendsen CN, Caldwell MA, Ostenfeld T: Human neural stem cells: isolation, expansion and transplantation. Brain Pathol 1999; 9:499-513.

-11 Martins AH, Alves JM, Trujillo CA, Schwindt TT, Barnabe GF, Motta FL, Guimaraes AO, Casarini DE, Mello LE, Pesquero JB, Ulrich $\mathrm{H}$ : Kinin-B2 receptor expression and activity during differentiation of embryonic rat neurospheres. Cytometry A 2008;73:361-368.

$\checkmark 12$ Reynolds BA, Tetzlaff W, Weiss S: A multipotent EGF-responsive striatal embryonic progenitor cell produces neurons and astrocytes. J Neurosci 1992;12:4565-4574.

$\checkmark 13$ Reynolds BA, Weiss S: Generation of neurons and astrocytes from isolated cells of the adult mammalian central nervous system. Science 1992;255:1707-1710.

14 Reynolds BA, Weiss S: Clonal and population analyses demonstrate that an EGF-responsive mammalian embryonic CNS precursor is a stem cell. Dev Biol 1996;175: $1-13$.

15 Einstein O, Ben-Menachem-Tzidon O, Mizrachi-Kol R, Reinhartz E, Grigoriadis N Ben-Hur T: Survival of neural precursor cells in growth factor-poor environment: implications for transplantation in chronic disease. Glia 2006;53:449-455.

16 Ben-Hur T: Immunomodulation by neural stem cells. J Neurol Sci 2008;265:102-104.
17 Pluchino S, Zanotti L, Rossi B, Brambilla E, Ottoboni L, Salani G, Martinello M, Cattalini A, Bergami A, Furlan R, Comi G, Constantin G, Martino G: Neurosphere-derived multipotent precursors promote neuroprotection by an immunomodulatory mechanism. Nature 2005;436:266-271.

18 Sheng WS, Hu S, Ni HT, Rowen TN, Lokensgard JR, Peterson PK: TNF-alpha-induced chemokine production and apoptosis in human neural precursor cells. J Leukoc Biol 2005;78:1233-1241.

19 Zheng XS, Yang XF, Liu WG, Pan DS, Hu WW, Li G: Transplantation of neural stem cells into the traumatized brain induces lymphocyte infiltration. Brain Inj 2007;21:275278.

20 Louis SA, Reynolds BA: Generation and differentiation of neurospheres from murine embryonic day 14 central nervous system tissue. Methods Mol Biol 2005;290:265-280.

21 Feitoza CQ, Sanders H, Cenedeze M, Camara NO, Pacheco-Silva A: Pretreatment with indomethacin protects from acute renal failure following ischemia-reperfusion injury. Transplant Proc 2002;34:2979-2980.

22 Grimaldi P, Rossi F: Lack of neurogenesis in the adult rat cerebellum after Purkinje cell degeneration and growth factor infusion. Eur J Neurosci 2006;23:2657-2668.

23 Ponti G, Peretto P, Bonfanti L: A subpial, transitory germinal zone forms chains of neuronal precursors in the rabbit cerebellum. Dev Biol 2006;294:168-180.

24 Klein C, Butt SJ, Machold RP, Johnson JE, Fishell G: Cerebellum- and forebrainderived stem cells possess intrinsic regional character. Development 2005;132:44974508.

25 Capone C, Frigerio S, Fumagalli S, Gelati M, Principato MC, Storini C, Montinaro M, Kraftsik R, Curtis MD, Parati E, Simoni MG Neurosphere-derived cells exert a neuroprotective action by changing the ischemic microenvironment. PLoS ONE 2007;2:e373.

26 Chute JP: Stem cell homing. Curr Opin Hematol 2006;13:399-406.

-27 Krampera M, Glennie S, Dyson J, Scott D, Laylor R, Simpson E, Dazzi F: Bone marrow mesenchymal stem cells inhibit the response of naive and memory antigen-specific T cells to their cognate peptide. Blood 2003;101 3722-3729.
28 Djouad F, Plence P, Bony C, Tropel P, Apparailly F, Sany J, Noel D, Jorgensen C: Immunosuppressive effect of mesenchymal stem cells favors tumor growth in allogeneic animals. Blood 2003;102:3837-3844.

-29 Spaggiari GM, Capobianco A, Becchetti S, Mingari MC, Moretta L: Mesenchymal stem cell-natural killer cell interactions: evidence that activated NK cells are capable of killing MSCS, whereas MSCS can inhibit IL-2-induced NK-cell proliferation. Blood 2006;107: 1484-1490.

30 Stagg J, Pommey S, Eliopoulos N, Galipeau J: Interferon-gamma-stimulated marrow stromal cells: a new type of nonhematopoietic antigen-presenting cell. Blood 2006;107: 2570-2577.

31 Burne MJ, Daniels F, El Ghandour A, Mauiyyedi S, Colvin RB, O’Donnell MP, Rabb H: Identification of the CD4(+) $\mathrm{T}$ cell as a major pathogenic factor in ischemic acute renal failure. J Clin Invest 2001;108:1283-1290.

>32 Yokota N, Burne-Taney M, Racusen L, Rabb $\mathrm{H}$ : Contrasting roles for STAT4 and STAT6 signal transduction pathways in murine renal ischemia-reperfusion injury. Am J Physiol Renal Physiol 2003;285:F319-F325.

33 Shen XD, Ke B, Zhai Y, Gao F, Anselmo D, Lassman CR, Busuttil RW, Kupiec-Weglinski JW: Stat4 and Stat6 signaling in hepatic ischemia/reperfusion injury in mice: $\mathrm{HO}-1$ dependence of Stat4 disruption-mediated cytoprotection. Hepatology 2003;37:296303.

-34 Rabb H, Daniels F, O’Donnell M, Haq M, Saba SR, Keane W, Tang WW: Pathophysiological role of $\mathrm{T}$ lymphocytes in renal ischemia-reperfusion injury in mice. Am J Physiol Renal Physiol 2000;279:F525-F531.

35 Ji JF, He BP, Dheen ST, Tay SS: Interactions of chemokines and chemokine receptors mediate the migration of mesenchymal stem cells to the impaired site in the brain after hypoglossal nerve injury. Stem Cells 2004; 22:415-427. 